\title{
Metode Fuzzy Vector Quantization Untuk Kompresi Citra RGB Motif Batik Pekalongan
}

\author{
Widiyono \\ email: widdyono@gmail.com \\ Teknik Informatika, STMIK Widya Pratama
}

\begin{abstract}
Abstrak
Batik Pekalongan merupakan warisan nenek moyang yang menjadi salah satu sumber penghidupan masyarakat Pekalongan. Batik Pekalongan memiliki ciri khas motif banyak warna yang dapat dijadikan bermacam-macam jenis model pakaian. Beberapa motif batik khas Pekalongan yang memiliki banyak warna seperti Jlamprang, Liong, Buketan, Sawat, Semen, dan Terang bulan. Seiring perkembangan teknologi informasi pemasaran batik pekalongan banyak yang menggunakan marketplace. Citra kain batik dengan desain banyak warna memiliki kapasitas storage data yang besar. Demikian juga saat upload citra motif batik pada perdagangan secara daring. akan membutuhkan bandwidth yang besar, sedangkan kendala pada pengusaha UMKM hanya memiliki access koneksi bandwidth internet yang terbatas. Beberapa penelitian melakukan kompresi citra untuk mendapatkan ukuran bit citra lebih kecil tetapi tidak mengurangi kualitas informasi yang terkandung dalam citra. Kompresi citra dengan teknik Fuzzy Vector Quantization pada citra RGB dapat mengurangi banyak bit tetapi tidak menghilangkan informasi kualitas citra yang terkandung didalamnya. Teknik vector quantization akan mengelompokan citra menjadi beberapa blok dan menentukan pusat cluster atau codeword. Susunan codeword berdasarkan urutan kode vektor citra merupakan pembentukan codebook, dimana kualitas citra terkompresi tergantung pada kualitas codebook. Kualitas codeword lebih baik diperoleh dengan penerapan Metode Fuzzy pada proses vector quantization. Kompresi citra dilakukan dengan memisahkan terlebih dahulu citra Red, Green, Blue ke masing-masing lapisan. Kemudian dilakukan proses kompresi model FVQ, yang selanjutnya disatukan kembali menjadi citra berwarna. Penelitian ini dapat mengurangi kapasitas bit citra dan tidak mengurangi kualitas informasi citra berekstensi Joint Photographic (jpg). Perhitungan Mean Square Error(MSE) citra hasil kompresi menunjukan error lebih rendah, dan hasil perhitungan Peak Signal to Noise Ratio (PSNR) lebih tinggi yang berarti kualitas citra tidak banyak berubah walaupun terdapat pengurangan kapasitas bit citra RGB.
\end{abstract}

Kata kunci : batik pekalongan, kompresi citra RGB, fuzzy vector quantization

\section{Pendahuluan}

Kota Pekalongan dengan ikon "Kota Batik" merupakan penghasil batik di Jawa Tengah, Industri batik menyumbangkan kemajuan besar bagi perekonomian Pekalongan dan merupakan sumber kehidupan masyarakat Kota Pekalongan dan sekitarnya. Sebagai sasaran target pemasaran batik ke luar negeri maka dipublikasikan Branding "Pekalongan World's City of Batik" selain itu sebagai peningkatan publikasi sektor wisata, seni dan budaya [1]. Ikon kota Pekalongan ini diharapkan dapat mengenalkan Kota Pekalongan lebih luas ke berbagai negara.

Usaha Mikro, Kecil dan Menengah (UMKM) memiliki peran yang sangat penting dan strategis dalam pembangunan ekonomi nasional, penyerapan tenaga kerja dan pendistribusian hasil pembangunan [2]. Tantangan utama UMKM dan
Pengusaha batik dalam pemasaran batik bagi pengusaha untuk menjangkau pasar internasional yaitu akses pemasaran dan daya saing. Penggunaan teknologi informasi merupakan salah satu cara pengusaha batik dalam pemasarannya secara luas. Model pemasaran dan transaksi secara online sering disebut e-commerce dikembangkan dalam bentuk e-marketplace untuk meningkatkan tingkat kepercayaan terhadap konsumen batik yang melakukan pembelian melalui online [3].

Pemasaran batik melalui online seperti emarketplace atau e-commerce dengan cara mengunggah gambar atau citra motif batik baik berupa model pakaian atau lembaran kain merupakan cara yang umum dan mudah dilakukan oleh pengusaha. Mengunggah citra motif batik agar menarik konsumen kebanyakan dengan citra berwarna, dikarenakan ciri khas 
batik Pekalongan yaitu motif batik dengan keanekaragaman warna. Motif batik berwarna biasanya memiliki resolusi yang besar sehingga kapasitas ukuranya besar. Citra batik yang berukuran besar menimbulkan masalah pada pengiriman data (data transmission) akan membutuhkan waktu yang lama. Maka dibutuhkan kompresi citra batik sebelum mengunggah ke pemasaran online. Kompresi adalah sebuah metode yang bertujuan untuk mengecilkan ukuran file citra [4].

Informasi citra digital saat ini terjadi kendala kurangnya berimbang antara kecanggihan fungsi sistem dengan kenyamanan dan efektifitas tampilan sistem informasi yang dibuat, sedangkan pengguna sistemnya manusia yang alat inputnya mata atau visual sangat peka terhadap kenyamanan dan keindahan [5]. Informasi digital berupa motif batik yang beraneka ragam warna dan motif tampak indah tetapi kurang memperhatikan kapasitas data yang akan berpengaruh saat proses publikasi secara daring atau online.

Citra digital yang dihasilkan kamera memiliki resolusi besar, seiring bertambah baik kemampuan untuk mengambil dan menyimpan citra dari peralatan tersebut [6] . Kendala dalam transformasi citra untuk mengunggah motif batik pada marketplace yang dilakukan UMKM dan pengusaha batik adalah terbatasnya access koneksi internet yang dimiliki. Citra motif batik tersebut juga akan diteruskan kepada penjual online reseller dan dropshipper yang kebanyakan menggunakan smartphone. Kebutuhan citra motif batik dalam kapasitas kecil diperlukan untuk memudahkan pengunggahan dan mengurangi kapasitas penyimpanan. Kondisi throughput yang rendah dalam jaringan menginspirasi pengguna internet untuk berpikir mendapatkan solusi terbaik dalam kecepatan transformasi data citra yang lambat. Pengurangan kapasitas citra dengan tidak menghilangkan informasi yang terkandung dalam citra dikembangkan untuk mengatasi kendala kelambatan transformasi data citra. Teknik kompresi citra banyak penelitian dilakukan untuk memperkecil ukuran citra berwarna sebelum ditransformasikan melalui internet. Kompresi citra bertujuan mengkonversi file data ke dalam file yang lebih kecil untuk penyimpanan yang efisien dan transmisi data yang efektif. Kompresi citra menggunakan teknik lossy menggunakan metode vector quantization [7]. Metode vektor kuantisasi merupakan pemetaan data citra berupa bit yang tidak beraturan, sehingga dalam pemetaan menggunakan metode Fuzzy. Metode fuzzy pada vektor kuantisasi, diterapkan karena metode fuzzy salah satu metode metode analisa yang tidak pasti dalam pemetaan data (Ida Afriliana, Arfan Haqiqi Sulasmoro, Ali Sofyan 2019)[8]. Kompresi citra pada motif batik berwarna dengan metode vektor kuantisasi akan dapat mengurangi kapasitas ukuran citra lebih kecil dengan dipengaruhi oleh jenis motif dan warna.

\section{Metode Penelitian}

Metode penelitian yang digunakan dalam penelitian ini meliputi lima langkah utama yaitu studi literatur, pengumpulan data, eksperimen kompresi citra RGB, analisa hasil kompresi, pengujian MSE dan PSNR. Metode penelitian ini diperlihatkan seperti Gambar 1.

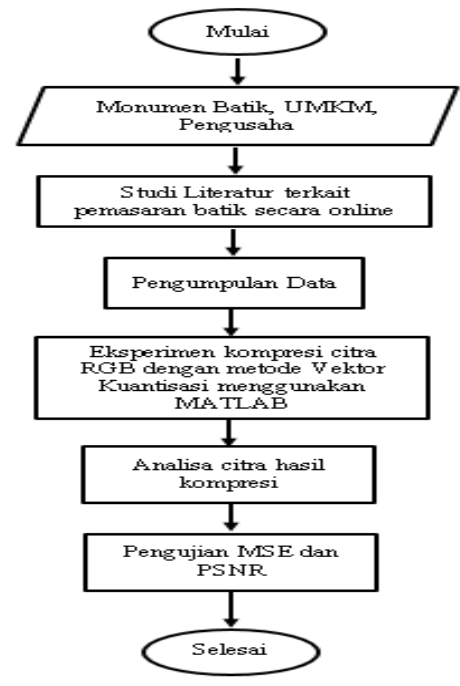

Gambar 1. Metode Penelitian

\section{A. Studi Literatur}

Studi literatur dilakukan dengan kegiatan mencari referensi yang relevan terkait dengan penelitian yang sedang dilakukan. Sumber literatur yang digunakan berasal dari buku, jurnal, prosiding, dan penelitian yang dilakukan sebelumnya, dikarenakan penelitian ini merupakan lanjutan dari penelitian Kompresi Citra Grayscale dengan metode Fuzzy Vektor Kuantisasi yang sudah pernah dilakukan 
sebelumnya. Studi literatur ini tentunya bisa memperkuat kualitas penelitian yang akan dilakukan. Tinjauan pustaka penelitian ini dengan pembahasan sebagai berikut:

1) Citra RGB (red, green, blue)

Definisikan citra digital adalah suatu fungsi dua variabel, $f(x, y)$, notasi $x$ dan y adalah koordinat spasial sedangkan nilai $\mathrm{f}(\mathrm{x}, \mathrm{y})$ yang merupakan intensitas citra pada koordinat. Dasar untuk menampilkan dan menciptakan warna citra digital berdasarkan pada lapisan matrix pixel, dimana sebuah warna merupakan kombinasi dari tiga warna dasar, yaitu Red, Green, Blue, (RGB) [8]. Warna RGB adalah suatu model warna yang terdiri dari red, green, dan blue, yang digabungkan dalam suatu susunan warna yang banyak warna. Setiap warna dasar, contohnya merah, akan diberi rentang nilai setiap pixel pada monitor, nilai setiap pixel antara rentang paling 0 adalah paling kecil dan 255 paling besar. Skala 256 didasarkan pada pengukuran 8 digit bilangan biner yang digunakan pada mesin layar monitor. Sehingga akan diperoleh kombinasi warna campuran sebanyak 256 x 256 x 256 yaitu 1677726 jenis warna.

2) Kompresi Citra

Kompresi citra merupakan teknik pengolahan citra yang bertujuan mengurangi ukuran bit citra. Teknik kompresi dibedakan menjadi dua yakni lossless compression dan lossy compression.

Lossless compression yaitu teknik yang memproses data asli menjadi bentuk yang lebih kecil ukuran kapasitasnya tanpa hilangnya informasi, biasanya digunakan pada aplikasi biomedis. Lossy compression yaitu teknik mendapatkan data yang lebih ringkas dengan melalui suatu proses kuantisasi dari data asli dengan tingkat error yang dapat diterima [9].

Teknik Vector Quantisation salah satu model kompresi citra yang membentuk codebook dengan cara meng-cluster citra masukan menjadi beberapa blok dan menentukan pusat cluster yang merupakan vektor jarak terpendek dari setiap blok cluster. Algoritma clustering yang digunakan dalam merancang VQ dengan Fuzzy sehingga metode kuantisasinya dinamakan Fuzzy Vector Quantization.

3) Metode Vector Quantization

Metode kuantisasi (quantization) merupakan metode kompresi jenis lossy yang banyak digunakan peneliti karena berhasil mengurangi banyak bit. Teknik kompresi citra dengan Kuantisasi vektor merupakan proses pemetaan vektor dari ruang vektor ke bagian ruang vektor citra. Bagian ruang vektor ini disebut sebagai cluster dan direpresentasikan dengan pusat vektor atau centroids atau codeword. Suatu himpunan centroids yang merepresentasikan seluruh ruang vektor disebut codebook. vektor k-dimensi pada ruang vektor $\mathrm{R}^{\mathrm{k}}$ ke dalam vektor himpunan terbatas $\mathrm{Y}=\left\{\mathrm{y}_{\mathrm{i}}: \mathrm{i}=1,2, \ldots, \quad \mathrm{N}\right\}$. Vector quantization dapat direpresentasikan seperti persamaan (1) berikut [10] :

$$
V_{i}=\left\{x \in R^{k}\left\|x-y_{i}\right\| \leq\left\|x-y_{j}\right\|, j \neq . i\right\} . .
$$

Tahapan kompresi kuantisasi yaitu pertama membagi citra input menjadi beberapa set vector. Kemudian vektor yang terbentuk akan dijadikan data training untuk diurutkan menjadi set vektor yang disebut codebook, pembentukan codebook ini bertujuan untuk menyediakan satu set vektor yang menghasilkan distorsi minimal antara citra asli dan citra vektor kuantisasi. Kualitas citra hasil kompresi tergantung dari kualitas baik tidaknya codebook yang dibuat.

4) Fuzzy Vector Quantization

Fuzzy vector quantization merupakan teknik kompresi pemetaan piksel citra inputan yang akan mengelompokkan citra menjadi beberapa blok citra. Setiap blok citra yang terdiri dari beberapa piksel akan di cluster untuk menentukan piksel pusat cluster atau codeword. Beberapa codeword perwakilan tiap blok citra akan disusun membentuk codebook. Codebook akan menjadi acuan dalam pembentukan kode vektor citra. Sehingga baik buruknya kualitas citra kompresi tergantung pada kualitas codebook.

Proses kompresi citra pada teknik kuantisasi melalui tahapan coding dan 
decoding. Proses coding dengan menyusun matrik menjadi satu kolom sejumlah $\mathrm{N}$ baris, kemudian di cluster menjadi $\mathrm{C}$ cluster dan menentukan pusat cluster (codeword) berdasarkan fuzzy c-mean. Decoding merupakan proses ekstraksi dari code vektor menjadi matrik citra sesuai dengan codebook yang terbentuk dari proses kuantisasi. Selanjutnya hasil decoding berupa matrik piksel yang memiliki intensitas sesuai codebook akan ditampilkan ke bentuk citra. Citra yang terbentuk merupakan citra hasil kompresi fuzzy vector quantization.

5) Pengujian Hasil Kompresi Citra

Pengujian kompresi citra dilakukan dengan metode perbandingan antara citra sebelum dikompresi dengan citra sesudah dilakukan proses kompresi. Pengujian ini perlu dilakukan karena kompresi yang terlalu banyak menghilangkan bit akan berpengaruh buruk pada kualitas citra. PSNR (Peak Signal to Noise Ratio ) adalah perbandingan citra sebelum kompresi dengan citra terkompresi. Sebelum menghitung PSNR terlebih dahulu menghitung Mean Square Error(MSE) adalah nilai error kuadrat rata-rata antara citra asli dengan citra terkompresi [11]. MSE dapat dihitung dengan persamaan (2) dan (3) berikut.

$$
\begin{aligned}
M S E & =\frac{\sum_{x=1}^{M} \sum_{y=1}^{N}(g(x, y)-f(x, y))^{2} \ldots . .(2)}{M x N} \\
\text { PSNR } & =20 x \log _{10} \frac{\max |g(x, y)| \ldots . .(3)}{\sum_{x=1}^{M} \sum_{y=1}^{N}(g(x, y)-f(x, y))^{2}}
\end{aligned}
$$

Keterangan:

$$
\begin{aligned}
\mathrm{M} & \text { : lebar citra } \\
\mathrm{N} & \text { : panjang citra } \\
\mathrm{f}(\mathrm{x}, \mathrm{y}) & \text { : } \\
& \text { intensitas piksel dari citra } \\
& \text { asli pada koordinat }(\mathrm{x}, \mathrm{y}) \\
\mathrm{g}(\mathrm{x}, \mathrm{y}) & \text { : } \\
& \text { intensitas piksel dari citra hasil } \\
& \text { kompresi pada koordinat }(\mathrm{x}, \mathrm{y}) .
\end{aligned}
$$

Hasil perhitungan MSE dan PSNR dapat diartikan bahwa semakin besar nilai MSE akan semakin banyak perubahan nilai piksel yang terjadi antara citra masukan dan citra keluaran. Sedangkan semakin besar nilai PSNR maka kualitas citra keluaran semakin menyerupai citra masukannya. Rentang nilai PSNR untuk citra dengan kualitas visual yang dianggap baik pada kompresi lossy sekitar 30-50 dB [12].

\section{B. Pengumpulan Data}

Tahapan pengumpulan data dilakukan dengan observasi dan wawancara. Observasi dilakukan di Monumen Batik Pekalongan untuk mendapatkan data motif batik khas Pekalongan. Kemudian wawancara dengan pengusaha batik dan UMKM Batik Pekalongan untuk mendapatkan informasi kendala pada pemasaran batik menggunakan marketplace atau secara daring/online. Pemasaran batik yang dipilih difokuskan pada pemasaran secara daring/online dengan mengunggah citra digital motif batik khas Pekalongan terdapat kendala pada unggah gambar di marketplace. Dikarenakan gambar yang di unggah tersebut akan diunggah kembali oleh para penjual sebagai reseller. Sedangkan para reseller kebanyakan hanya menggunakan smartphone dan akses internet yang terbatas. Sehingga salah satu cara untuk memperlancar kegiatan pemasaran daring dengan memperkecil kapasitas citra batik. Data yang diperoleh dari pengumpulan data yang digunakan dalam penelitian ini citra batik jenis Jlamprang, Liong, Buketan, Sawat, Semen, dan Terang bulan. Gambar 2. merupakan tampilan data citra yang digunakan pada penelitian ini.

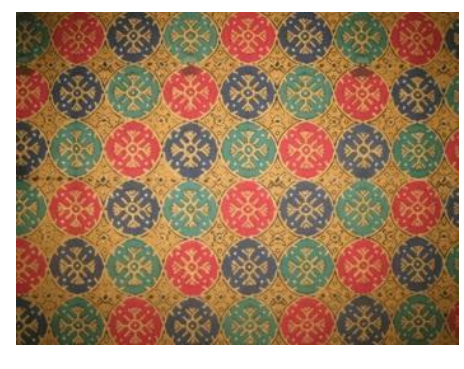

Jlamprang .jpg 


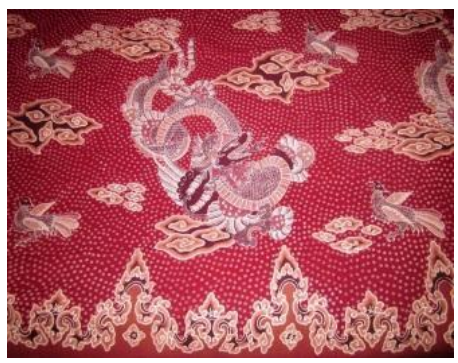

Liong .jpg

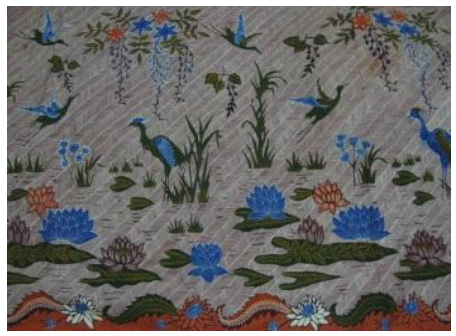

Buketan.jpg

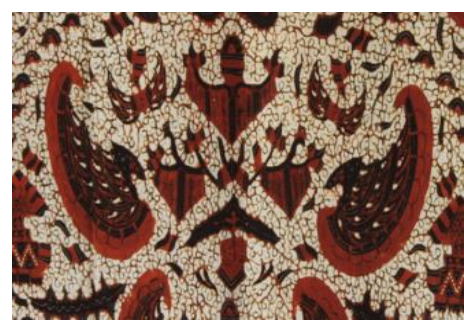

Sawat.jpg

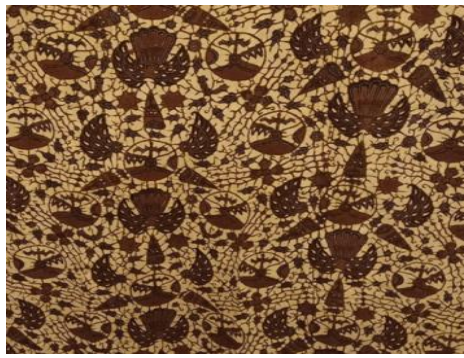

Semen .jpg

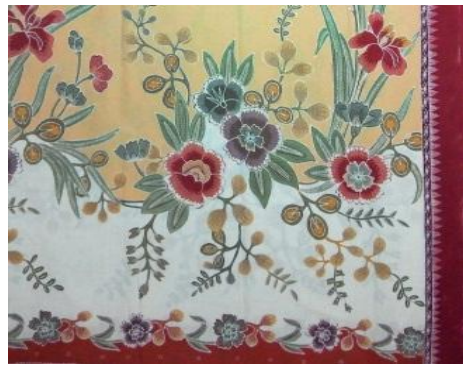

Terangbulan .jpg

Gambar 2. Motif Batik Khas Pekalongan Citra motif batik khas Pekalongan seperti Gambar 2. Merupakan data inputan kompresi citra RGB dengan metode Fuzzy Vector
Quantization. Sedangkan kapasitas data masingmasing citra Gambar 2. masing-masing tidak sama. Kapasitas citra motif batik sebagai data penelitian seperti diperlihatkan pada Tabel 1 .

Tabel 1. Ukuran Data Citra Motif Batik

\begin{tabular}{|l|c|}
\hline Nama citra & $\begin{array}{c}\text { Ukuran } \\
\text { bit }\end{array}$ \\
\hline Jlamprang.jpg & $664 \mathrm{~kb}$ \\
\hline Liong.jpg & $295 \mathrm{~kb}$ \\
\hline Buketan.jpg & $149 \mathrm{~kb}$ \\
\hline Sawat.jpg & $611 \mathrm{~kb}$ \\
\hline Semen.jpg & $559 \mathrm{~kb}$ \\
\hline Terang bulan.jpg & $222 \mathrm{~kb}$ \\
\hline
\end{tabular}

\section{Eksperimen Kompresi Citra}

Tahapan eksperimen dilakukan dengan software Matlab R2015b. Dengan tahapan seperti gambar diagram yang diperlihatkan Gambar 3.

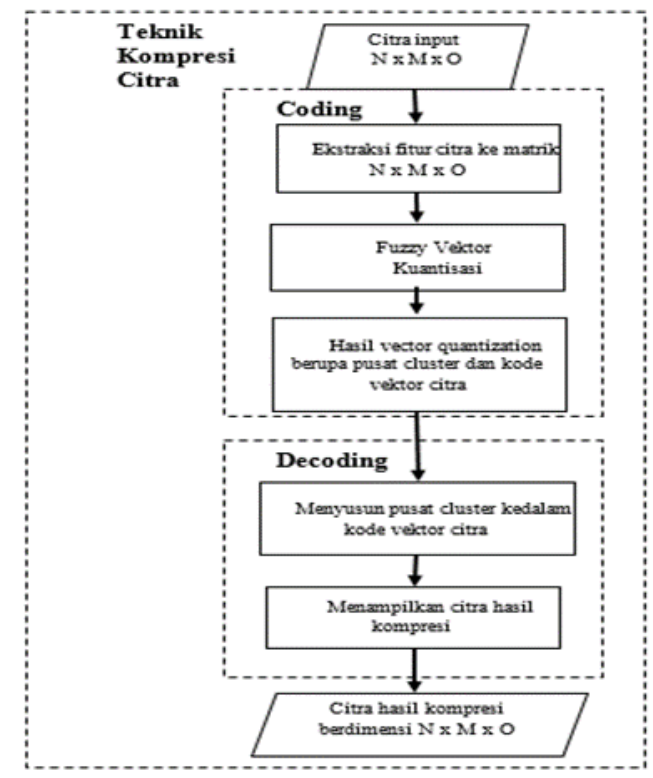

Gambar 3. Diagram Teknik Vector Quantization

Kode program Matlab R2015b sesuai diagram Gambar 3. Teknik kompresi vector quantization dapat ditampilkan sebagai berikut:

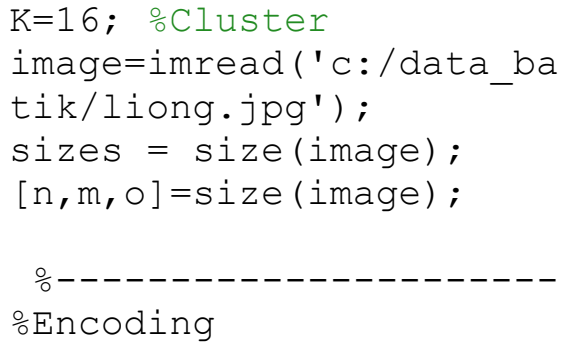


dengan citra setelah dikompresi menggunakan aplikasi Matlab R2015b sebagai berikut:

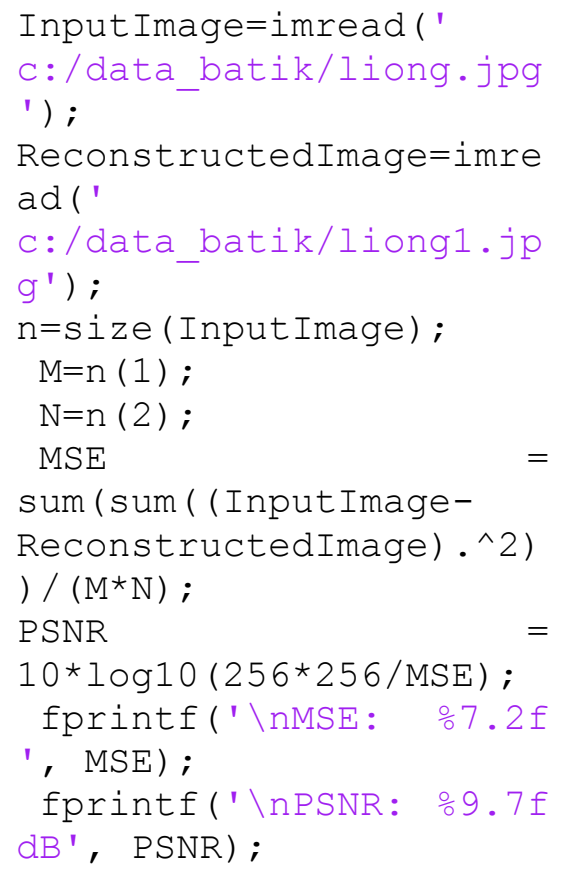

Hasil proses dari aplikasi MSE dan PSNR seperti Gambar 5. Proses ini dilakukan semua data citra motif batik. Pada Gambar 5 terdapat tampilan MSE tiga baris karena perbandingan dilakukan setiap layer bit yakni layer bit R (red), layer bit $\mathrm{G}$ (green) dan layer bit B (blue). Demikin juga untuk PSNR sama seperti perhitungan MSE. Kemudiaan dari ketiga layer tersebut dirata-rata untuk mendapatkan hasil perhitungan MSE dan PSNR setiap citra motif batik.

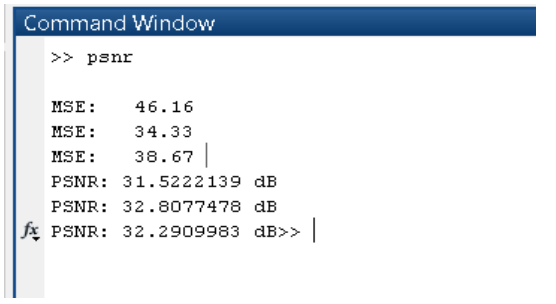

Gambar 5. Tampilan Matlab hasil proses perhitungan MSE dan PSNR

\section{Hasil dan Pembahasan}

Penelitian ini melakukan kompresi citra motif batik khas Pekalongan dengan metode Fuzzy Vector Quantization yang diimplementasikan pada aplikasi Matlab R2015b dengan data penelitian sejumlah enam citra. Citra hasil kompresi memiliki ukuran yang ditampilkan pada Tabel 2.Pengurangan bit setiap citra motif batik berbeda-beda tergantung pada proses cluster pembentukan codeword. Perwakilan nilai resolusi setiap pixel untuk membentuk codeword didasarkan pada motif dan warna, sehingga jika warna citra dan motif berbeda sangat menentukan kualitas codeword. Kualitas codeword ini, ketika disusun menjadi codebook maka berpengaruh besarnya pengurangan bit setiap pixel.

Kompresi citra RGB dengan metode Fuzzy Vector Quantization, dengan data citra motif batik yang memiliki motif dan warna berbedabeda akan berpengaruh besar pada tingkat kompresi atau pengurangan ukuran bit citra. Sehingga prosentase pengurangan bit citra setiap data citra tidak sama. Hasil eksperimen kompresi citra dari enam citra motif batik dapat ditampilkan seperti Tabel 2.

Tabel 2. Kapasitas ukuran file setelah citra dikompresi

\begin{tabular}{|c|l|c|c|c|}
\hline No & Jenis Motif & $\begin{array}{c}\text { Sebelum } \\
\text { Kompresi } \\
(\mathbf{K b})\end{array}$ & $\begin{array}{c}\text { Sesudah } \\
\text { Kompresi } \\
(\mathbf{K b})\end{array}$ & $\begin{array}{c}\text { Prosentase } \\
\text { pengurangan } \\
\text { bit }\end{array}$ \\
\hline 1 & Jlamprang.jpg & 664 & 73 & 89.01 \\
\hline 2 & Liong.jpg & 295 & 239 & 18.98 \\
\hline 3 & Buketan.jpg & 149 & 147 & 1.34 \\
\hline 4 & Sawat.jpg & 611 & 71 & 88.38 \\
\hline 5 & Semen.jpg & 559 & 79 & 85.87 \\
\hline 6 & Terangbulan.jpg & 222 & 121 & 45.50 \\
\hline
\end{tabular}

Pengurangan bit citra yang terlalu banyak akan mengurangi kualitas citra ataupun kualitas informasi yang terkandung pada citra tersebut. Pada citra digital terdapat standar pengukuran error untuk menentukan kualitas citra, yakni MSE dan PSNR. Besar atau kecilnya nilai PSNR ditentukan oleh besar kecilnya nilai MSE pada citra. Semakin besar nilai PSNR, maka semakin baik hasil yang diperoleh pada tampilan citra hasil kompresi. Sebaliknya, semakin kecil nilai PSNR, maka akan semakin buruk hasil kualitas citra hasil kompresi. Nilai dari PSNR dan MSE diberi satuan, yaitu decibel (dB). Hubungan nilai PSNR dengan nilai MSE yaitu semakin besar nilai PSNR, akan semakin kecil nilai MSE-nya.

Penggunaan PSNR secara umum untuk mengukur kualitas citra. Sedangkan MSE adalah kesalahan/error kuadrat rata-rata nilai pixel citra. Nilai MSE diperoleh dengan membandingkan nilai selisih piksel-piksel citra sebelum kompresi dengan citra hasil kompresi pada posisi piksel yang sama. Semakin besar 
nilai MSE, maka tampilan pada citra hasil kompresi akan semakin buruk., semakin kecil nilai MSE, maka tampilan pada citra hasil akan semakin baik. Hasil perhitungan MSE dan PSNR citra ditampilkan seperti pada Tabel 3.

Tabel 3. Hasil perhitungan MSE dan PSNR citra

\begin{tabular}{|c|c|c|c|c|c|c|c|c|c|}
\hline \multirow{2}{*}{ No } & \multirow{2}{*}{ enis Motr } & \multicolumn{4}{|c|}{ MSE (BS) } & \multicolumn{4}{|c|}{$\mathrm{PSNR}(\mathrm{AB})$} \\
\hline & & red & green & But & Eenta & red & grem & blue & refate \\
\hline 1 & flumprangifs & 3193 & 2090 & 3365 & 2883 & 3312 & 3496 & 3280 & 3060 \\
\hline 2 & Liscaging & 4516 & 3433 & 3967 & 39.72 & 3152 & 3281 & 3229 & 32.21 \\
\hline 3 & Buketanipg. & 427 & 388 & 492 & 436 & 41.86 & 4227 & 4125 & Al. $\%$ \\
\hline 4 & Suntipg & 3438 & 1759 & 3239 & 2812 & 3280 & 35.71 & 33.06 & 3026 \\
\hline 5 & Eemenjpg & 27.75 & 2451 & 2902 & 2709 & 33.73 & 3421 & 33.54 & 3083 \\
\hline 6 & Teratguin ifs & 2203 & 199 & 2213 & 21.66 & 3473 & 3517 & 3472 & 3487 \\
\hline
\end{tabular}

Berdasarkan hasil perhitungan rata rata PSNR yang ditampilkan Tabel 3. Maka citra hasil kompresi metode Fuzzy Vector Quantisation pada citra RGB motif batik semua hasil eksperimen diantara $30 \mathrm{~dB}$ sampai dengan $50 \mathrm{~dB}$ yang berarti bahwa citra hasil kompresi dengan metode Fuzzy Vector Quantisation berkualitas baik, walaupun banyak pengurangan bit pada citra hasil kompresi.

\section{Kesimpulan}

Kompresi citra motif batik dengan metode Fuzzy Vector Quantisation dapat memperkecil ukuran bit citra. Pengurangan bit citra ditentukan oleh proses pembentukan codeword yang disusun menjadi codebook dimana banyak dipengaruhi oleh jenis motif dan jenis warna citra batik. Citra hasil kompresi sesuai perhitungan MSE dan PSNR diantara 32,21 dB41,79 dB masih sesuai standar kualitas citra yakni $30 \mathrm{~dB}-50 \mathrm{~dB}$ sehingga citra hasil kompresi dapat dinyatakan kualitas baik walaupun banyak pengurangan ukuran bit pada citra.

\section{Daftar Pustaka}

[1] Ernawati, Aan Erlansari, Widhia K.Z. Oktoeberza. "Kompresi Citra Batik Besurek Menggunakan Discrete Wavelet Transform." Seminar Nasional Teknologi Informasi Dan Komunikasi X, 2018: 6.

[2] Hersanto Fajri. Dewi Primasari, M. Hadid Awaludin. "Implementasi Desain Visual Media Informasi Digital menggunakan Prinsip Rule Of Thirds."
KREA-TIF Jurnal Teknik Informatika 5 (2017): 8.

[3] Himanshu Gupta, Ritesh Kumar, Soni Changlani. Enhanced Data Hiding Capacity Using LSB-Based Image Steganography Method. International Journal of Emerging Technology and Advanced Engineering, 2013.

[4] Ida Afriliana, Arfan Haqiqi Sulasmoro, Ali Sofyan. "Implementasi Fuzzy

Sugeno Untuk Kinerja Pengajaran Dosen." Smart Comp , 2019: 4.

[5] Kamaldeep Joshi, Rajkumar Yadav, Sachin Allwadhi. PSNR and MSE

Based Investigation of LSB.

International Conference on Computational Techniques in Information and Communication Technologies , 2016.

[6] Miftahur Rohman, Ida Anisah. "Teknik Kompresi Citra Menggunakan Metode Vektor Kuantisasi Berbasis Fuzzy C-Means." eprints.upnjatim.ac.id, 2013: 8.

[7] Raras Krasmala, Arif Budimansyah Purba, U. Tresna Lenggana. Kompresi Citra Dengan Menggabungkan Metode Discrete Cosine Transform (DCT) dan Algoritma Huffman. 2017.

[8] Rifda Amalia, Susanti. "Strategi City Branding Pekalongan World's City Of Batik." Seni Budaya. jurnal.isiska.ac.id, 2018: 15.

[9] Safaruddin Hidayat Al Ikhsan, Fety Fatimah, Riyan Saputra Irawan. "Aplikasi Android Sebaran Lokasi UMKM di Kota Bogor Dengan Formula Haversine." KREA-TIF, Jurnal Teknik Informatika 7 (2019): 15.

[10] Taryadi, Era Yunianto, Nur Ika Royani. "Analisis Tingkat Kesiapan Adopsi E-Marketplace UMKM Batik Di Pekalongan." Jurnal LITBANG Kota Pekalongan 8 (2015): 15. 
[11] Utami Rahma Sari Lubis, Mesran, Taronisokhi Zebua. Implementasi Algoritma Chua Chaotic Noise Pada Enkripsi Citra RGB. KOMIK (Konferensi Nasional Teknologi Informasi dan Komputer), 2017.

[12] Veronica Lusiana, Budi Hartono. "Praproses Citra Menggunakan Kompresi Citra, Perbaikan Kontras,
Dan Kuantisasi Piksel." Prosiding SINTAK 2017, 2017: 5.

[13] Yuniarti, Anny, Nadya Anisa Syafa, Handayani Tjandrasa. Aplikasi

Kompresi Citra Berbasis Rough Fuzzy Set. 2010. 